\title{
Brand Loyalty in the Smartphone User's: The Role of Brand Credibility and Consumer Convenience
}

\author{
RESISTA VIKALIANA ${ }^{1}$, ROYMON PANJAITAN ${ }^{2}$, ECHAN ADAM ${ }^{3}$, MUHAMMAD IQBAL FASA $^{4}$, \\ ASTIL HARLI ROSLAN ${ }^{5}$ \\ ${ }^{1}$ Department of Logistics Management, INSTITUT ILMU SOSIAL DAN MANAJEMEN STIAMI, INDONESIA. \\ E-mail: resistav31@gmail.com \\ ${ }^{2}$ Faculty of Economics and Business, UNIVERSITAS SAINS DAN TEKNOLOGI KOMPUTER. INDONESIA. \\ E-mail: roymon@stekom.ac.id \\ ${ }^{3}$ Faculty of Agriculture, UNIVERSITAS NEGERI GORONTALO, INDONESIA. E-mail: echanadam@ung.ac.id \\ ${ }^{4}$ Faculty of Islamic Economics and Business, UNIVERSITAS ISLAM NEGERI RADEN INTAN LAMPUNG, INDONESIA. \\ E-mail: miqbalfasa@radenintan.ac.id \\ 5UNIVERSITAS MUHAMMADIYAH KENDARI, INDONESIA. E-mail: astilharliroslan7@gmail.com
}

\begin{abstract}
This study analyzes consumer loyalty from attitudes on credible knowledge sources and the emotional experience due to the first perception Data was collected from 107 smartphone users through questionnaires and interviews. The SEM-PLS compound technique was used to analyze the data with a pathway mediated by the comfort decision of credibility on brand loyalty. The results show that there is a positive correlation between a consumer's attitude and brand credibility. Furthermore, experiential marketing positively influences the brand hallo effect and consumers attitude, which directly impacts decision convenience, brand credibility and loyalty. However, there is a negative relationship between decision convenience and brand loyalty. Similarly, a decision convenience relationship has not processed credibility in brand loyalty. This study shows that customer loyalty can be influenced by their attitude, which provides a positive signal to brand credibility. The examined Model helps managers understand how the branding process investment may provide confidence in brand loyalty based on comfortable brand decisions.
\end{abstract}

Keywords: Consumers Attitude; Experiential Marketing; Decision Convenience

JEL Classification: C1, L2 


\section{Introduction}

Business growth is increasingly dynamic due to the emergence of different brands, influencing customer loyalty to different products or services. In today's digital world, it is not easy to gain and maintain consumer loyalty to a product because the media has a strong, positive and direct influence on the knowledge advantages of the trademark community. The important thing that becomes the urgency in this study is whether the decision of convenience in using smartphone products is still based on brand credibility derived from the experience of a brand that has an impact on consumer behavior? and is there any implication of the experience of a brand gives rise to a hallo effect that implies a decision of convenience to remain loyal to the brand of the product?. Thus, the influence of social media indirectly affects the loyalty and attitude of consumers towards the brand. Consequently, this social media influence indirectly affects loyalty and consumers' attitude towards brands. ((Huang et al., 2018); J. Kim \& Lee, 2019).

An individual's reaction towards the news objective truth has no direct effect on a brand's behavioral intentions. Visentin et al., (2019) stated that advertising will not be negatively affected by fake news when a brand is credible. This because credibility is confidence in the brand's position of product information depending on users' perception and the company's ability to describe how consumers evaluate honesty and expertise.(Chakraborty, 2019; Lou \& Yuan, 2019). Similarly, brand experience affects consumers directly and offers actionable insights for managerial practice to find previous research showing credibility, perceived quality, and perceived satisfaction (Dwivedi et al., 2018); Othman et al., 2017). However, it is harder to satisfy customers who threaten the brand's credibility with increasingly high service failures. Therefore, the ease to use and obtaining product information during the selection of credible brand preferences improves perception over the faithfulness to the product.

According to S. Kim \& Choi (2018), understanding the underlying mechanisms of the information process managerially improved the strategic experience of product provision. Brand reputation with the high congruence effect of product categories results in positive advertising and sponsorship attitudes, behavioral intentions, sponsorship, and message credibility Richetin et al., (2019) \& Shin \& Ki, (2019). Vila-López \& Rodríguez-Molina, (2013) stated that there is an optimistic connection among marketing proficiency because, on first impressions, the halo effect obtains several profits, including appearance, character, and reputation. Similarly, Chao, (2015) and Yeh et al., (2019) stated that strengthened experimental marketing plays an essential function in building brand impressions and service innovation. Comparably, the hallo effect impacts one's visual appeal and emotional response felt at a later stage Minge \& Thüring, (2018). The experiences of an originally good product brand can be obscured by the negative interpretation of the halo effect. This causes speedy perception and generalization of a negative brand's reputation. Zeigler-Hill et al., (2020), established that a negative correlation to interference in oral communication accompanied by negative stereotypes forms social stigma. The hallo effect's first impression threatens interpretation in measuring the brand experience and strength which leads to incorrect conclusions in an applied context. The halo effect influence inconsistency can be pragmatically assessed with the visual aesthetic affecting the initially perceived usability. These outcomes suggest a substantiation predisposition among positive evidence and search for communication, particularly, data regarding buyers without an attitude, or a progressive outlook about reputation. Also, report search only transforms reputation when clients do not prejudge. Therefore, to examine previous research inconsistencies, there is need to study consumer comfort decisions for brand loyalty.

The use of credibility and convenience of decisions as the mediators of the relationship model between consumer attitudes, brand loyalty and credibility are the novelty of this study. The brand credibility mediation function, indicated trust, expertise, and power, contributes positively to connecting consumer attitudes with brand loyalty. According to Jeon (2017) \& Setyawan \& Kussudiyarsana (2015), the emotional bond between consumer attitudes and brand credibility is a critical variable mediation in building relational exchange loyalty. This study was conducted in the 
context of the behavior of smartphone users in indonesia because there are two crucial reasons. Firstly the motivation of people's behavior is comfortable making decisions based on the selection of the level of credibility of the product. Consumers have a positive response and other people's recommendations take precedence over those that can be directly seen and heard from other consumers (LepkowskaWhite, 2013). Second, the emergence of hallo effect can be a pragmatic consideration of a person in making decisions on the convenience of using the product even though it has a distinctive experience. In another study, originality is based on the importance of convenience decisions as mediation to measure consumer attractiveness and the ability to change product knowledge and ease information access and product use (Berry et al., 2002 \& Sabine et al., 2009). Therefore, both variables are essential in developing loyalty.

There are inconsistent results in previous studies regarding brand loyalty. Therefore, the purpose of this study is to reanalyze the brand of the product based on four stages. The initial stage combines complex interpretations of interconnected philosophical systems by theoretically and empirically supporting interactions between CA, BC, and DC. At the methodological stage, symmetrical and asymmetric statistical methods are combined to examine possibilities and correlations between CA, $\mathrm{BC}$, or BL. The third stage shows that brand loyalty levels can be optimal by combining convenience decisions and credibility for a competitive edge. According to the final stage experiential marketing contributes to integrating emotional experiences during the hallo effect and expression of consumer attitudes. The practical implications of brand loyalty can be built from the brand's product philosophy, but empirically to improve the smartphone retail business in particular must prioritize credibility and prevent negative hallo effects from the onset of product competitiveness. These findings certainly seek to provide a conceptual policy for traditional business owners to innovate and maintain brand loyalty from newer and more attractive competitive products.

\section{Literature Review and Research Hypothesis}

\subsection{Experiential Marketing}

The buying encounter is completed when customers browse for items, buy, collect, and use them (El Naggar \& Bendary, 2017). According to Storey (2017), corporations develop secure, efficient, sustainable, and stable advertising partnerships. This is in line with Ihtiyar et al., (2019), which stated that a market experience occurs whenever a company intentionally utilizes services and products as advice for commercial consumers. Moreover, a good shopping experience relates to positive consumer attitudes towards brand (Nayeem, 2019; De Vukkiers \& Chuchu, 2018; Lee et al., 2017: Shamim \& Albinsson).

The joy caused by a good shopping experience is an indicator of changes in the psychological element of the consumer. Moreover, the emotional outcome of a good marketing experience is an important factor in creating a consumer attitude that directly influences the halo effect. ( $\mathrm{H}$. M. Jeon et al., 2020);(A Dwivedi et al., 2019); (Hung et al., 2016). Conclusively, customer experience influences the halo effect based on the concepts below.

H1: Experiential marketing is positively related to customer attitude.

H2: Experiential marketing is positively related to brand hallo effect

\subsection{Consumers Attitude}

Customers' treatment and effects strongly drive their attitude towards products. For instance, when consumers are treated badly, hatred of the product develops. According to (Andrews \& Shimp, 2017), the attitudes toward a project rely on the brand's understanding of customers and is a good attitude indicator. The brand response is a consumer's propensity to evaluate the brands, based on previous experience (Sheeraz et al., 2016). Therefore, based on correlation, a good consumer attitude increases brand credibility (Chin, 2020, Qureshi et al., 2020). 
Consumers derive value from useful content forming a more favorable attitude which causes greater brand loyalty (Lou et al., 2019). Although satisfaction is not a driving factor to customer loyalty, it reinforces brand's attitude (Smith, 2020). Dekhil \& Khammassi (2017) stated that companies should emphasize customer satisfaction and trust, which forms the basis of loyalty. According to Wang et al. (2017), attitude increases brand credibility and enhance loyalty (Pourazad et al., 2019).

H3: Consumer's attitude is positively related to brand credibility.

H4: Consumer's attitude is positively related to brand loyalty which influences credibility

\subsection{Brand Credibility}

Brand credibility is the legitimacy of consumer data in a market to meet expectations or promises. (S.-H. Lee et al., 2016) stated that to develop customer loyalty, companies need brand credibility. Furthermore, there is a positive relationship between brand credibility and true loyalty (Mathew \& Thomas, 2018).

Sellers need to know when customer expectations for comfort in buying a product increases for innovation and trust to be developed (Duarte, Costa e Silva, et al., 2018). Moreover, brand credibility have a direct relationship, hence should be considered in consumer decision making ((Jun, 2020); (Jeng, 2016).

According to Kashif (2018), brand credibility refers to a state where customer needs significantly affect loyalty. However, there are other factors that customers consider, including prices or services offered.

H5: Brand credibility is positively related to brand loyalty.

H6: Brand credibility is positively related to decision convenience

H7: Brand credibility is not positively related to brand loyalty toward decision convenience

\subsection{Brand Hallo Effect}

The halo theory describes the impact of an aspect from the complete' to 'specific', addressing the prejudiced generalizability (Woo, 2019). In general human distortions present when evaluating a single person or entity are generalized by prejudging a certain attribute into other qualities (Utami et al., 2017).

Nicolau et al., (2020) stated that the halo effect is a perceptual illusion where people convey their perspectives regarding a product depending on its predisposition to some other trait. Moreover, the halo effect is a pattern that influence the customer's trust in a branded product or its credibility.

Brand is one of the intrinsic properties of an enterprise (Atulkar, 2020). Halo effect occurs when the appraisal of a certain product quality greatly affects or distorts the interpretation its other elements (Apaolaza et al., 2017).

Studies show that customers judge a commodity based on comprehensive impressions compared to unique performance indicators. The halo impact is an invisible framework with measuring problem, though with major influence on consumer choices (Jin \& Lee, 2019); Bacig \& Young, 2019).

H8: Brand hallo effect is positively related to decision convenience

\subsection{Decision Convenience}

The emphasis on consumers' desire for greater convenience has heightened in recent years (A. Wong, 2020). Consumer comfort is a multidimensional structure, including decision convenience as one of its aspects (Duarte, e Silva, et al., 2018)(Ahmadi, 2019; Roy et al., 2020). According to Shahijan et al. (2018), decision making involves customers' product demand, subsequent retailer choice, and the bid to pick. Knowledge of vendors and their competitors influences possibility and consistent decision-making (Kumar et al., 2020). 
Behavior implications and previous studies show that service convenience helps asses consumer experience in an entire quality (Berry, 2016). According to García-Fernández et al. (2018), there is a key precedent for customer's actions. DC is critical in understanding the overall service comfort (Benoit et al., 2017).

Convenience has a positive correlation with satisfaction, hence mpacts repurchase and loyalty (Kumar et al., 2020; Mehmood \& Najmi, 2017); (García Fernández et al., 2016). Loyalty positively affect repurchasing preferences, apart from playing a major role in buying behavior. A. Wong, (2020) and Chadwick \& Piartrini (2019) established that DC is the most significant predictor of store loyalty, though these two variables have a positive correlation.

\section{H9: Decision convenience is positively related to brand loyalty.}

\subsection{Brand Loyalty}

Loyalty is a powerful marketing term, reflecting the degree to which a brand is committed to a customer. Executives make projections based on brand loyalty levels to ensure the buyer stays on the mark, even when costs or accomplishments change (Kwon et al., 2020).

$\mathrm{BL}$ is among the oldest and most studied marketing structures due to its superior results (Costa Filho et al., 2020). Moreover, it is a two-dimensional structure that contains attitudes and behavior, reflected in repetitive purchase actions (Arifine et al., 2019; Ngobo, 2017).

The value of BL has been recognized by practitioners and marketing scholars, viewing it as an indicator of commitment that motivates consumers to repurchase a chosen brand (Bairrada et al., 2018); (Atulkar \& Kesari, 2017; Coelho et al., 2018; Giovanis \& Athanasopoulou, 2018). According to (Atulkar \& Kesari, 2018; Koo et al., 2020), consumers are pleased with the products are less susceptible to retail costs, and give a favorable buy-in regarding a business.

Managers oversee product construction, partnerships, and customer BL development (Cuong et al., 2020). Bu et al., (2020) stated that practical and social principles inspire consumers to be faithful to the culture and different brands.

\section{Methodology}

\subsection{Variable Measurement}

Data was collected using a five-point Likert scale questionnaire, ranging from 1 for strongly disagree to 5 for agree. In several social and behavioral sciences studies, there are encounters of theoretical construct (s) that cannot be observed directly. (Ramayah et al., 2018) .

In this study, the endogenous and exogenous factor were latent variables, including Consumer's Attitude, Experiential Marketing, Brand Loyalty, Brand Credibility, Brand Hallo Effect, and Decision Convenience. The exogenous an endogeneous variables include Consumer's Attitude and Experiential Marketing, and Brand Loyalty, Credibility, Hallo Effect, and Decision Convenience.

\subsection{Population, Sample, and Sampling Technique}

The population of this study was smartphone users in Indonesia. Furthermore, a questionnaire was prepared and sent out to through convenience sampling. The questionnaire was distributed online in June- July 2020, though 107 questionnaires were returned.

\subsection{Data Analysis Techniques}

Data was analysed using Partial Least Square (PLS) technique, shifting from covariance-based SEM to variant-based approaches (Ramayah et al., 2018). The study analysed the relationship between information quality and skills as well as technology using the structural equation modelling technique. 


\section{Results and Discussion}

\subsection{Results}

\subsubsection{Test of Structural Models (Inner Model)}

The results of Structural Equation Modelling (SEM-PLS) were analyzed by evaluating structural equation models. SEM-PLS used two approaches, including assessment of the factor analysis (external model) to determine validity and reliability measures of latent variables. The test criteria for validity and reliability in this study are linear and convergent, and composite approach (K. K. K.-K. Wong, 2013). To analyze the relationship between building the importance value and the R-square, the inner model was tested. Moreover, the Bootstrap resampling evaluated the interior templates in SEM-PLS research.

\subsubsection{Discriminant validity}

Linear validity was examined through the analysis of the association between variables with other frameworks in model simulation. The indicator item loading value needs to be greater than the crossloading of the other construct (J. F. Hair et al., 2017). Fornell \& Larcker (1981), when AVE squared root is more than the value between the latent variables and above 0500 , discriminant validity exists. Table 2 shows the results of cross-loading, AVE, and AVE root values of latent variables used.

Table 1 The value of discriminant validity

\begin{tabular}{|l|c|c|c|c|c|c|}
\hline \multirow{2}{*}{ Items } & \multicolumn{6}{|c|}{ Construct } \\
\cline { 2 - 7 } & $\mathbf{X 1}$ & $\mathbf{X 2}$ & $\mathbf{X 3}$ & $\mathbf{Z 1}$ & $\mathbf{Z 2}$ & $\mathbf{Y}$ \\
\hline X1.1 & 0.904 & 0.626 & 0.416 & 0.475 & 0.558 & 0.463 \\
\hline X1.2 & 0.927 & 0.710 & 0.516 & 0.489 & 0.634 & 0.525 \\
\hline X2.1 & 0.677 & 0.818 & 0.477 & 0.494 & 0.580 & 0.409 \\
\hline X2.2 & 0.543 & 0.791 & 0.352 & 0.563 & 0.687 & 0.551 \\
\hline X2.3 & 0.470 & 0.733 & 0.500 & 0.413 & 0.413 & 0.443 \\
\hline X2.4 & 0.563 & 0.862 & 0.557 & 0.615 & 0.704 & 0.558 \\
\hline X2.5 & 0.627 & 0.740 & 0.320 & 0.519 & 0.611 & 0.513 \\
\hline X3.1 & 0.352 & 0.432 & 0.847 & 0.273 & 0.387 & 0.480 \\
\hline X3.2 & 0.443 & 0.470 & 0.835 & 0.238 & 0.412 & 0.430 \\
\hline X3.3 & 0.484 & 0.512 & 0.843 & 0.402 & 0.479 & 0.468 \\
\hline Z1.1 & 0.334 & 0.462 & 0.270 & 0.804 & 0.574 & 0.311 \\
\hline Z1.2 & 0.433 & 0.510 & 0.280 & 0.818 & 0.514 & 0.273 \\
\hline Z1.3 & 0.535 & 0.659 & 0.366 & 0.898 & 0.713 & 0.582 \\
\hline Z2.1 & 0.529 & 0.543 & 0.382 & 0.582 & 0.790 & 0.525 \\
\hline Z2.2 & 0.415 & 0.580 & 0.380 & 0.511 & 0.811 & 0.461 \\
\hline Z2.3 & 0.653 & 0.748 & 0.498 & 0.698 & 0.889 & 0.548 \\
\hline Y.1 & 0.494 & 0.474 & 0.444 & 0.428 & 0.505 & 0.863 \\
\hline Y.2 & 0.520 & 0.667 & 0.519 & 0.451 & 0.612 & 0.848 \\
\hline Y.3 & 0.343 & 0.407 & 0.419 & 0.365 & 0.435 & 0.848 \\
\hline AVE & $\mathbf{0 . 8 3 8}$ & $\mathbf{0 . 6 2 5}$ & $\mathbf{0 . 7 0 8}$ & $\mathbf{0 . 6 9 1}$ & $\mathbf{0 . 7 0 7}$ & $\mathbf{0 . 7 2 8}$ \\
\hline Square Root of AVE & $\mathbf{0 . 9 1 6}$ & $\mathbf{0 . 7 9 0}$ & $\mathbf{0 . 8 4 2}$ & $\mathbf{0 . 8 3 1}$ & $\mathbf{0 . 8 4 1}$ & $\mathbf{0 . 8 5 3}$ \\
\hline AVE = Average Variance Extracted; & & & & & \\
\hline Souryyyyyyy \\
\hline
\end{tabular}

Source: Data processed, 2020 
According to Table 1 , the value of the cross-loading indicator variable Consumer Attitude $(X 1)$ is above the cross-loading value of other latent variables. Similarly, Experiential Marketing (X2), Brand Hallo Effect (X3), Decision Convenience (Z1), Credibility (Z2), and Loyalty (Y) indicators were above the cross-loading value of other latent variables and greater than 0.700 . Therefore, the indicator used in the study was valid discriminant.

\subsubsection{Convergent validity}

The Loading value was used to test the convergent validity of each indicator. Table 2 below shows the value of convergent validity and consistency relliability

Table $\mathbf{2}$ The value of convergent validity and consistency reliability (CR)

\begin{tabular}{|c|c|c|c|}
\hline Construct & Items & OL's & CR \\
\hline \multirow[t]{2}{*}{ Consumer's Attitude (X1) } & $\mathrm{X} 1.1$ & 0.904 & 0.912 \\
\hline & $\mathrm{X} 1.2$ & 0.927 & \\
\hline \multirow[t]{5}{*}{ Experiential Marketing (X2) } & $\mathrm{X} 2.1$ & 0.818 & 0.892 \\
\hline & $\mathrm{X} 2.2$ & 0.791 & \\
\hline & $\mathrm{X} 2.3$ & 0.733 & \\
\hline & $\mathrm{X} 2.4$ & 0.862 & \\
\hline & $\mathrm{X} 2.5$ & 0.740 & \\
\hline \multirow[t]{3}{*}{ Brand Hallo Effect (X3) } & $\mathrm{X} 3.1$ & 0.847 & 0.879 \\
\hline & $\mathrm{X} 3.2$ & 0.835 & \\
\hline & X3.3 & 0.843 & \\
\hline \multirow[t]{3}{*}{ Decision Convenience (Z1) } & $\mathrm{Z} 1.1$ & 0.804 & 0.878 \\
\hline & $\mathrm{Z} 1.2$ & 0.818 & \\
\hline & $\mathrm{Z} 1.3$ & 0.898 & \\
\hline \multirow[t]{3}{*}{ Brand Credibility (Z2) } & $\mathrm{Z2.1}$ & 0.790 & 0.870 \\
\hline & $\mathrm{Z2.2}$ & 0.811 & \\
\hline & $\mathrm{Z2.3}$ & 0.889 & \\
\hline \multirow[t]{3}{*}{ Brand Loyalty (Y) } & Y.1 & 0.863 & 0.889 \\
\hline & Y.2 & 0.848 & \\
\hline & Y.3 & 0.848 & \\
\hline
\end{tabular}

Source: Data processed, 2020

According to Table 2 , all variable Loading values were greater than the acceptable threshold of 0700 , which confirmed convergent validity (K. K. K.-K. Wong, 2013).

\subsubsection{Internal Consistency Reliability}

The reliability of latent variable indicators in social research uses Cronbach's alpha and provides conservative measurements in PLS-SEM (K. K. K.-K. Wong, 2013). Bagozzi \& Yi 1988; Hair et al., 2011) suggested the use of composite reliability as a substitute. According to Table 3 , the variables used in this study have high internal reliability because all the values are greater than 0.600 .

\subsubsection{Goodness of Fit}

The structural model was evaluated using the $Q^{2}$ predictive relevance model that measures how well the observation value is generated. $Q^{2}$ is based on the coefficient of determination of the entire 
dependent variable. The $Q^{2}$ magnitude has a value range of $0<Q^{2}<1$. The closer to 1 the value is, the better the model. Table 4 shows the results of the manually calculated $Q^{2}$ value.

Table 3 The goodness of fit test results

\begin{tabular}{|c|c|c|}
\hline Endogenous Variable & $\mathbf{R}^{2}$ & $\mathbf{Q}^{2}$ \\
\hline Consumers attitude (X1) & 0.536 & \multirow{5}{*}{0.948} \\
\hline Brand Hallo Effect (X3) & 0.318 & \\
\hline Decision Convenience (Z1) & 0.530 & \\
\hline Brand Credibility (Z2) & 0.427 & \\
\hline Brand Loyalty (Y) & 0.386 & \\
\hline
\end{tabular}

Source: Data processed, 2020

The table 3 above shows that the predictive relevance $\left(Q^{2}\right)$ value was 0948. This means the accuracy of this research model based on the diversity of Consumer Attitude, Experiential Marketing, Hallo Effect, Decision Convenience, Brand Credibility, and Loyalty is $94.8 \%$. The remaining $5.20 \%$ is influenced by other variables not included in this research model. Therefore, the model have a good estimation value and can be used for hypothesis testing.

\subsection{6. $t$-Statistics of Path Coefficients (Hypothesis Testing)}

Hypothesis is conducted to examine the value of the line coefficient and the model's Tstatistic.Based on the conceptual framework, the relationship model and hypothesis testing between variables are completed in two parts, specifically the direct impact coefficient pathway, and indirect influence path mediation testing. The hypothesis is tested after the model is declared appropriate and results are shown in Figure 1 (direct influence testing)

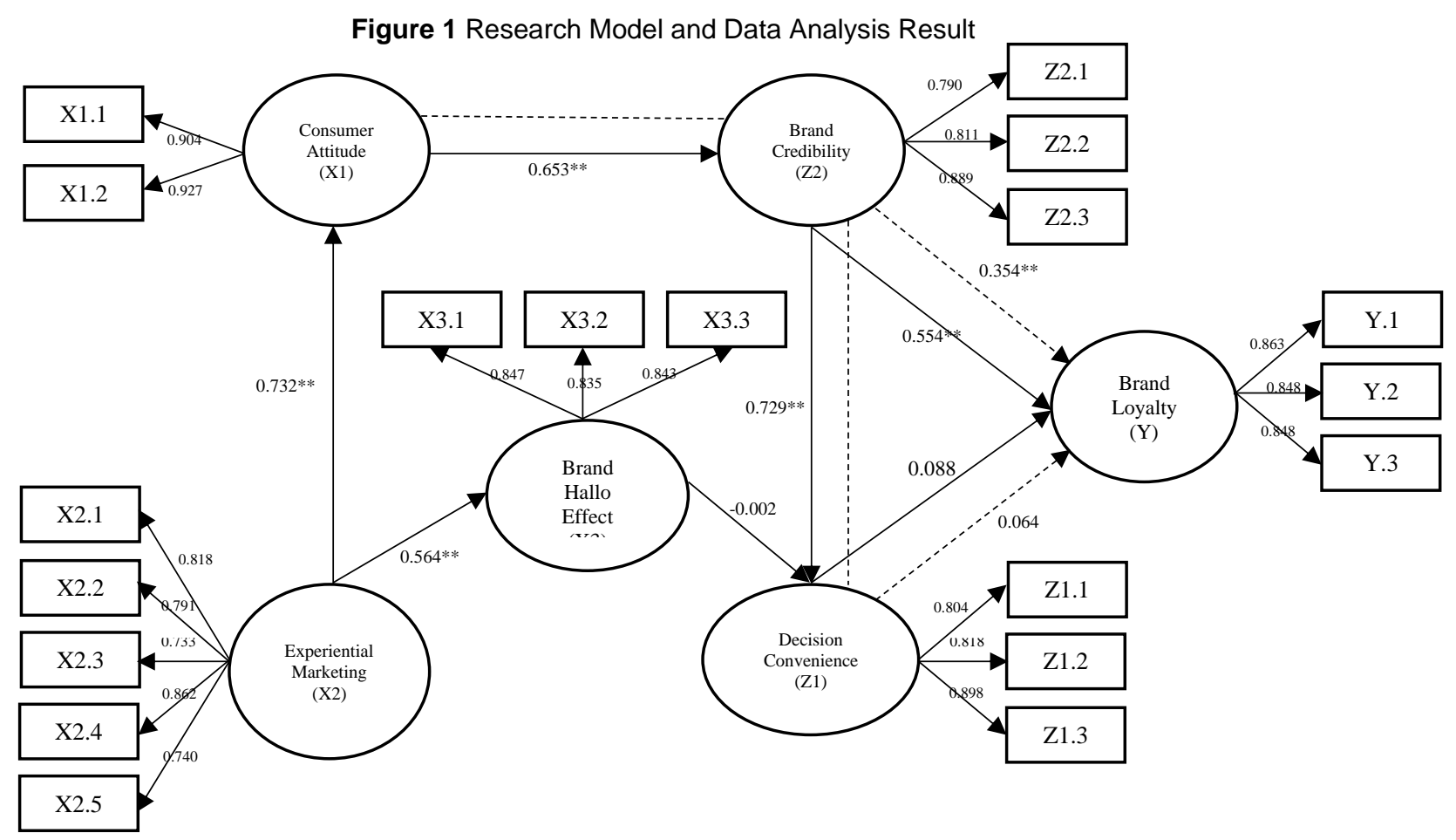

Source: Result of SEM-PLS- Primary Data Processed, 2020

Based on data analysis, all the hypotheses tested have a t-Statistics value greater than 1.96 or a P-value of $<0.05$, except $\mathrm{H} 4$ and $\mathrm{H} 6$. Therefore, the relationship between the variables were significant and acceptable. 


\subsection{Discussion}

This study shows that brand credibility and consumer convenience increase android user loyalty in Indonesia. Moreover, the results provide relevant information for smartphone sellers, helping them focus on factors that directly and indirectly affect customer loyalty.

According to the results, consumer attitude has a significant effect on brand credibility (H3). Seemingly, a better consumer attitude towards an android smartphone product improves its brand credibility and builds confidence in the quality of product information. Other consumers' attitudes towards products are a learned predisposition to respond to an object in a consistently pleasant way. Therefore, when another user is trusted, fulfilment of expectations is guaranteed (Delgado-Ballester, 2004). (Erdem \& Swait, 1998); (Srinivasan \& Ratchford, 1991) established that a good consumer response reflects the information quality, product position, lower risk perception, and cost-efficiency in data collection and decision-making. This is in line with Wang et al. (2017) and Spears \& Singh (2004). According to Wang et al. (2017), consumers think and trust the brand more when it is supported by a more reliable person.

This research also shows that brand credibility has a significant effect on customer loyalty (H5). Therefore, a higher android smartphone credibility increases brand loyalty. Products with value and supported by the latest features increase brand appeal loyalty. People are more likely to recommend a brand when they believe in it. This is in line with Rizwan et al. (2014); Alam et al., (2012), which established that brand credibility makes consumers loyal, even in the presence of competitors. (Sweeney \& Swait, 2008) stated that quality brands build a sustainable and strong trust between manufacturers and customers, increasing brand loyalty.

Indirect consumer attitude increases brand loyalty through credibility (H4). There is statistically significant evidence that the influence of consumer attitude on brand loyalty is mediated by credibility. This means that brand loyalty cannot be created only with a positive consumer attitude without credibility. This is in line wth Duan et al. (2008); Park \& Kim (2008) and Tsang et al. (2004). Consumer confidence demonstrated by buyers' attitude towards a product also makes the brand more credible.

Brand credibility has a positive and significant influence on decision convenience (H6). (Erdem \& Swait, 2004) stated that product and trust in brand information make consumers comfortable in making decision and understanding product capabilities and quality. Therefore, decision convenience, reflected by obtaining information and using products comfortably, prove that its brand has been well received by the user. This study is in with (Kumar et al., 2020; Seiders et al., 2007). The smartphone brand and its competitors may consistently determine decision-making for users using available information.

There is no sufficient evidence to suggest that decision convenience may increase brand loyalty (H9). However, Chadwick \& Piartrini (2019) stated that the concept of convenience can increase user loyalty towards a brand. Similarly, the study proved that the hypothesis convenience mediates the relationship between brand credibility and loyalty $(H 7)$ insignificantly. This is in line (Farquhar \& Rowley, 2009); (Carrigan \& Szmigin, 2006), which stated that convenience is verynambiguous and inconsistent in determining brand loyalty.

Experiential marketing influences brand hallo effects ( $H 2)$ and consumer attitude (H1) positively, proving the hypothesis of this study. Experiential marketing variables can increase the brand hallo effect and consumer attitude towards android smartphones. Similarly, (Jurisic \& Azevedo, 2011); (Swaminathan Sylvia Long-Tolbert Brian Till \& Brian Till, 2006) established that consumer experience and marketing perception enhances the brand halo effect. When a brand suits the user's needs, trust and loyalty is enhanced. According to (Halstead et al., 1996; Wirtz \& Bateson, 1995) Wu \& Petroshius (1987), experience did not have a significant influence on the halo effect. In this context, smartphone sellers use products to create a marketing experience and influence consumers' decision making, showing that good experiential marketing affects attitudes towards products. Moreover, increased experiential marketing improves user loyalty to products or brands owned from the services provided and advertisements on electronic media. According to Zarantonello \& Schmitt (2010), consumers want 
products that give them exclusive and unforgettable opportunities. Also, Maghnati \& Ling (2013) Moon et al. (2008) stated that a good experience determines the consumer's attitude in purchasing products.

According to the result, the brand halo effect does not sufficiently influence decision convenience $(H 8)$, hence cannot be used as leverage that consumers will feel comfortable without sufficient experience. In this study more value and attractiveness were considered the same on all product brands and did not depend on convenience effects in using it. Previous (Gong et al., 2015) and (Bacig \& Young, 2019) reported that the halo effect on service products and local labels has a major impact on consumer choice. However, that was not proven in this study because technology product changes faster. According to Leuthesser et al., (1995), the halo effect measures customer decision making errors regardless of comfortability. However, Apaolaza et al., (2017) revealed that decision making depends on the specific product quality features that greatly affects or distorts the interpretation of its other elements.

\section{Conclusion and Limitations}

This research determined how brand loyalty is influenced by consumer attitude and marketing experiences. The results show that the indicator of brand credibility success as a direct or indirect ruler creates a significant relationship with product loyalty. Furthermore, comfort decision mediation does not positively impact the need for confidence from the credibility of brand knowledge to change the decision in the consumer's mind. Since consumers are increasingly objective in assessing products, their decisions are not influenced by the halo effect. Similarly, a comfortable decision cannot influence a person's certainty to always be faithful to a brand. A good product marketing experience leads to a positive consumer attitude to remain faithful to a brand. Therefore, brand interpretation needs to be continuously examined through subsequent research. Studies can be developed by adding an indicator of more specific consumer tastes amid global or local brand competitions that are increasingly radical and dynamic.

\section{References}

1. Ahmadi, A. (2019). Thai Airways: key influencing factors on customers' word of mouth. International Journal of Quality and Reliability Management, 36(1), 40-57. https://doi.org/10.1108/IJQRM-022018-0024

2. Alam, A., Usman Arshad, M., \& Adnan Shabbir, S. (2012). Brand credibility, customer loyalty and the role of religious orientation. Asia Pacific Journal of Marketing and Logistics, 24(4), 583-598. https://doi.org/10.1108/13555851211259034

3. Andrews, J. C., \& Shimp, T. A. (2017). Advertising, promotion, and other aspects of integrated marketing communications. Nelson Education.

4. Apaolaza, V., Hartmann, P., Echebarria, C., \& Barrutia, J. M. (2017). Organic label's halo effect on sensory and hedonic experience of wine: A pilot study. Journal of Sensory Studies, 32(1), e12243. https://doi.org/10.1111/joss.12243

5. Arifine, G., Felix, R., \& Furrer, O. (2019). Multi-brand loyalty in consumer markets: a qualitativelydriven mixed methods approach. European Journal of Marketing, 53(11), 2419-2450. https://doi.org/10.1108/EJM-07-2017-0474

6. Atulkar, S. (2020). Brand trust and brand loyalty in mall shoppers. Marketing Intelligence and Planning, 38(5), 559-572. https://doi.org/10.1108/MIP-02-2019-0095

7. Atulkar, S., \& Kesari, B. (2017). Satisfaction, loyalty and repatronage intentions: Role of hedonic shopping values. Journal of Retailing and Consumer Services, 39, 23-34.

8. Atulkar, S., \& Kesari, B. (2018). Role of consumer traits and situational factors on impulse buying: does gender matter? International Journal of Retail \& Distribution Management, 46(4), 386-405.

9. Bacig, M., \& Young, C. A. (2019). The halo effect created for restaurants that source food locally. Journal of Foodservice Business Research, 22(3), 209-238. https://doi.org/10.1080/15378020.2019.1592654 
10.Bagozzi, R. P., \& Yi, Y. (1988). On the evaluation of structural equation models. Journal of the Academy of Marketing Science, 16(1), 74-94. https://doi.org/10.1007/BF02723327

11.Bairrada, C. M., Coelho, F., \& Coelho, A. (2018). Antecedents and outcomes of brand love: Utilitarian and symbolic brand qualities. European Journal of Marketing, 52(3/4), 656-682.

12.Benoit, S., Klose, S., \& Ettinger, A. (2017). Linking service convenience to satisfaction: dimensions and key moderators. Journal of Services Marketing, 31(6), 527-538.

13.Berry, L. L. (2016). Revisiting "big ideas in services marketing" 30 years later. Journal of Services Marketing, 30(1), 3-6.

14.Berry, L. L., Seiders, K., \& Grewal, D. (2002). Understanding service convenience. Journal of Marketing. https://doi.org/10.1509/jmkg.66.3.1.18505

15.Bu, Q., Jin, Y., \& Li, Z. (2020). How does a customer prefer community or brand? The impacts of customer experience on customer loyalty based on the perspective of value co-creation. Journal of Contemporary Marketing Science, ahead-of-p(ahead-of-print). https://doi.org/10.1108/jcmars-022020-0009

16.Carrigan, M., \& Szmigin, I. (2006). "Mothers of invention": Maternal empowerment and convenience consumption. European Journal of Marketing, 40(9-10), 1122-1142.

17.Chadwick, C., \& Piartrini, P. S. (2019). Product quality, convenience and brand loyalty: A case study of Silverqueen's adolescent consumers. 12th International Conference on Business and Management Research (ICBMR 2018).

18.Chakraborty, U. (2019). The impact of source credible online reviews on purchase intention: The mediating roles of brand equity dimensions. Journal of Research in Interactive Marketing. https://doi.org/10.1108/JRIM-06-2018-0080

19.Chao, D. R.-F. (2015). The Impact of Experimental Marketing on Customer Loyalty for Fitness Clubs: Using Brand Image and Satisfaction as the Mediating Variables. The Journal of International Management Studies.

20.Chin, P. N. (2020). The impact of endorser and brand credibility on consumers' purchase intention: the mediating effect of attitude towards brand and brand credibility. Journal of Marketing Communications, 26(8), 896-912. https://doi.org/10.1080/13527266.2019.1604561

21.Coelho, P. S., Rita, P., \& Santos, Z. R. (2018). On the relationship between consumer-brand identification, brand community, and brand loyalty. Journal of Retailing and Consumer Services, 43, 101-110.

22.Costa Filho, M. C., Falcao, R. P. Q., \& Motta, P. C. de M. (2020). Brand loyalty among low-income consumers? Qualitative Market Research. https://doi.org/10.1108/QMR-07-2019-0080

23.Cuong, P. H., Nguyen, O. D. Y., Ngo, L. V., \& Nguyen, N. P. (2020). Not all experiential consumers are created equals: the interplay of customer equity drivers on brand loyalty. European Journal of Marketing, 54(9), 2257-2286. https://doi.org/10.1108/EJM-04-2018-0228

24.De Villiers, M. V., Chinomona, R., \& Chuchu, T. (2018). The influence of store environment on brand attitude, brand experience and purchase intention. South African Journal of Business Management, 49(1), 1-8. https://doi.org/10.4102/sajbm.v49i1.186

25.Delgado-Ballester, E. (2004). Applicability of a brand trust scale across product categories. European Journal of Marketing, 38(5/6), 573-592. https://doi.org/10.1108/03090560410529222

26.Duan, W., Gu, B., \& Whinston, A. B. (2008). The dynamics of online word-of-mouth and product sales-An empirical investigation of the movie industry. Journal of Retailing, 84(2), 233-242.

27.Duarte, P., Costa e Silva, S., \& Ferreira, M. B. (2018). How convenient is it? Delivering online shopping convenience to enhance customer satisfaction and encourage e-WOM. Journal of Retailing and Consumer Services, 44, 161-169. https://doi.org/10.1016/j.jretconser.2018.06.007

28.Duarte, P., e Silva, S. C., \& Ferreira, M. B. (2018). How convenient is it? Delivering online shopping convenience to enhance customer satisfaction and encourage e-WOM. Journal of Retailing and Consumer Services, 44, 161-169.

29.Dwivedi, A, Johnson, L. W., Wilkie, D. C., \& ... (2019). Consumer emotional brand attachment with social media brands and social media brand equity. ... Journal of Marketing.

30.Dwivedi, Abhishek, Nayeem, T., \& Murshed, F. (2018). Brand experience and consumers' 
willingness-to-pay (WTP) a price premium: Mediating role of brand credibility and perceived uniqueness. Journal of Retailing and Consumer Services. https://doi.org/10.1016/j.jretconser.2018.06.009

31.El Naggar, R. A. A., \& Bendary, N. (2017). The Impact of Experience and Brand trust on Brand loyalty, while considering the mediating effect of brand Equity dimensions, an empirical study on mobile operator subscribers in Egypt. The Business \& Management Review, 9(2), 16-25.

32.Erdem, T., \& Swait, J. (1998). Brand Equity as a Signaling Phenomenon, 7 J. CONSUMER PSYCHOL, 131.

33.Erdem, T., \& Swait, J. (2004). Brand credibility, brand consideration, and choice. Journal of Consumer Research, 31(1), 191-198.

34.Farquhar, J. D., \& Rowley, J. (2009). Convenience: A services perspective. Marketing Theory, 9(4), 425-438. https://doi.org/10.1177/1470593109346894

35.Fornell, C., \& Larcker, D. F. (1981). Evaluating Structural Equation Models with Unobservable Variables and Measurement Error. Journal of Marketing Research, 18(1), 39. https://doi.org/10.2307/3151312

36.García Fernández, J., Gálvez Ruiz, P., Velez Colon, L., \& Bernal García, A. (2016). Service convenience, perceived value, satisfaction, and loyalty: A study of consumers from low-cost fitness centers in Spain. Journal of Physical Education and Sport, 16 (4), 1146-1152., 16(4), 1146-1152.

37.Giovanis, A. N., \& Athanasopoulou, P. (2018). Consumer-brand relationships and brand loyalty in technology-mediated services. Journal of Retailing and Consumer Services, 40, 287-294.

38.Gong, X., Zhang, K. Z. K., \& Zhao, S. J. (2015). Halo Effect on the Adoption of Mobile Payment: A Schema Theory Perspective. International Conference on E-Technologies, 153-165.

39. Hair, J. F., Hult, G. T. M., Ringle, C. M., \& Sarstedt, M. (2017). A Primer on Partial Least Squares Structural Equation Modeling (PLS-SEM)., $2^{\wedge} n d^{\wedge} E d$. CA: Sage.

40.Hair, Joe F., Ringle, C. M., \& Sarstedt, M. (2011). PLS-SEM: Indeed a silver bullet. Journal of Marketing Theory and Practice, 19(2), 139-151. https://doi.org/10.2753/MTP1069-6679190202

41. Halstead, D., Morash, E. A., \& Ozment, J. (1996). Comparing objective service failures and subjective complaints: An investigation of domino and halo effects. Journal of Business Research. https://doi.org/10.1016/0148-2963(95)00170-0

42.Huang, T. K., Liao, C.-Y., Wang, Y.-T., \& Lin, K.-Y. (2018). How Does Social Media Interactivity Affect Brand Loyalty? Proceedings of the 51st Hawaii International Conference on System Sciences. https://doi.org/10.24251/hicss.2018.266

43.Hung, C.-C., Su, M.-J., \& Zhuang, W.-L. (2016). 3D Experiential Marketing in International Industrial Fair. Journal of Economics and Behavioral Studies, 8(1 (J)), 69-78.

44.Ihtiyar, A., Barut, M., \& Ihtiyar, H. G. (2019). Experiential marketing, social judgements, and customer shopping experience in emerging markets. Asia Pacific Journal of Marketing and Logistics, 31(2), 499-515. https://doi.org/10.1108/APJML-02-2018-0081

45.Jeng, S. (2016). The influences of airline brand credibility on consumer purchase intentions. Journal of Air Transport Management, 55, 1-8. https://doi.org/10.1016/j.jairtraman.2016.04.005

46.Jeon, H. M., Yoo, S. R., \& Kim, S. H. (2020). The Relationships among Experience, Delight, and Recollection for Revisit Intention in Chocolate Exposition. Sustainability.

47.Jeon, J.-E. (2017). The impact of brand concept on brand equity. Asia Pacific Journal of Innovation and Entrepreneurship. https://doi.org/10.1108/apjie-08-2017-030

48.Jin, C.-H., \& Lee, J.-Y. (2019). The Halo Effect of CSR Activity: Types of CSR Activity and Negative Information Effects. Sustainability, 11(7), 2067. https://doi.org/10.3390/su11072067

49.Jun, S. H. (2020). The effects of perceived risk, brand credibility and past experience on purchase intention in the Airbnb context. Sustainability (Switzerland), 12(12). https://doi.org/10.3390/su12125212

50.Jurisic, B., \& Azevedo, A. (2011). Building customer-brand relationships in the mobile communications market: The role of brand tribalism and brand reputation. In Journal of Brand Management (Vol. 18, Issues 4-5, pp. 349-366). https://doi.org/10.1057/bm.2010.37

51.Kim, J., \& Lee, K. H. (2019). Influence of integration on interactivity in social media luxury brand 
communities. Journal of Business Research. https://doi.org/10.1016/j.jbusres.2017.10.001

52.Kim, S., \& Choi, S. M. (2018). Congruence Effects in Post-crisis CSR Communication: The Mediating Role of Attribution of Corporate Motives. Journal of Business Ethics. https://doi.org/10.1007/s10551-016-3425-y

53.Koo, B., Yu, J., \& Han, H. (2020). The role of loyalty programs in boosting hotel guest loyalty: Impact of switching barriers. International Journal of Hospitality Management, 84(June 2019), 102328. https://doi.org/10.1016/j.ijhm.2019.102328

54.Kumar, R., Sachan, A., \& Dutta, T. (2020). Examining the Impact of e-Retailing Convenience Dimensions on Behavioral Intention: The Mediating Role of Satisfaction. Journal of Internet Commerce, O(0), 1-29. https://doi.org/10.1080/15332861.2020.1788367

55.Kwon, J. H., Jung, S. H., Choi, H. J., \& Kim, J. (2020). Antecedent factors that affect restaurant brand trust and brand loyalty: focusing on US and Korean consumers. Journal of Product and Brand Management, August. https://doi.org/10.1108/JPBM-02-2020-2763

56.Lee, J.-W., Park, E.-J., \& Choi, M. (2017). The study on the effect of outdoor experiential marketing on brand and purchase intentions. Journal of Digital Convergence, 15(5), 139-150.

57.Lee, S.-H., Workman, J. E., \& Jung, K. (2016). Brand relationships and risk: influence of risk avoidance and gender on brand consumption. Journal of Open Innovation: Technology, Market, and Complexity, 2(1), 14. https://doi.org/10.1186/s40852-016-0041-0

58.Lepkowska-White, E. (2013). Are they listening? Designing online recommendations for today's consumers. Journal of Research in Interactive Marketing. https://doi.org/10.1108/JRIM-07-20120027

59.Leuthesser, L., Kohli, C. S., \& Harich, K. R. (1995). Brand equity: the halo effect measure. European Journal of Marketing, 29(4), 57-66. https://doi.org/10.1108/03090569510086657

60.Lou, C., Xie, Q., Feng, Y., \& Kim, W. (2019). Does non-hard-sell content really work? Leveraging the value of branded content marketing in brand building. Journal of Product and Brand Management, 28(7), 773-786. https://doi.org/10.1108/JPBM-07-2018-1948

61.Lou, C., \& Yuan, S. (2019). Influencer Marketing: How Message Value and Credibility Affect Consumer Trust of Branded Content on Social Media. Journal of Interactive Advertising. https://doi.org/10.1080/15252019.2018.1533501

62.Maghnati, F., \& Ling, K. C. (2013). Exploring the relationship between experiential value and usage attitude towards mobile apps among the smartphone users. International Journal of Business and Management, 8(4), 1.

63. Mathew, V., \& Thomas, S. (2018). Direct and indirect effect of brand experience on true brand loyalty: role of involvement. Asia Pacific Journal of Marketing and Logistics, 30(3), 725-748. https://doi.org/10.1108/APJML-08-2017-0189

64.Mehmood, S. M., \& Najmi, A. (2017). Understanding the impact of service convenience on customer satisfaction in home delivery: Evidence from Pakistan. International Journal of Electronic Customer Relationship Management, 11(1), 23-43.

65.Minge, M., \& Thüring, M. (2018). Hedonic and pragmatic halo effects at early stages of User Experience. International Journal of Human Computer Studies. https://doi.org/10.1016/j.ijhcs.2017.07.007

66.Moon, H.-K., Youn, C.-R., Park, J.-E., \& Lee, Y.-R. (2008). The effects of perceived experiential marketing activity on consumers' attitude toward apparel brands. Fashion \& Textile Research Journal, 10(2), 181-190.

67.Nayeem, T. (2019). Brand experience and brand attitude: examining a credibility-based mechanism. Marketing Intelligence and Planning, 37(7), 821-836. https://doi.org/10.1108/MIP-11-2018-0544

68.Ngobo, P. V. (2017). The trajectory of customer loyalty: an empirical test of Dick and Basu's loyalty framework. Journal of the Academy of Marketing Science, 45(2), 229-250.

69.Nicolau, J. L., Mellinas, J. P., \& Martín-Fuentes, E. (2020). The halo effect: A longitudinal approach. Annals of Tourism Research, 83(April), 1-10. https://doi.org/10.1016/j.annals.2020.102938

70.Othman, M., Kamarohim, N., \& Nizam, F. M. (2017). Brand credibility, perceived quality and perceived value: A study of customer satisfaction. International Journal of Economics and 
Management.

71.Park, D.-H., \& Kim, S. (2008). The effects of consumer knowledge on message processing of electronic word-of-mouth via online consumer reviews. Electronic Commerce Research and Applications, 7(4), 399-410.

72.Pourazad, N., Stocchi, L., \& Pare, V. (2019). The power of brand passion in sports apparel brands. Journal of Product and Brand Management, 29(5), 547-568. https://doi.org/10.1108/JPBM-122018-2164

73.Qureshi, M. I., Khan, N., Qayyum, S., Malik, S., Sanil, H. S., \& Ramayah, T. (2020). Classifications of sustainable manufacturing practices in ASEAN region: A systematic review and bibliometric analysis of the past decade of research. Sustainability, 12(21), 8950.

74.Ramayah, T., Cheah, J., Cuah, F., Ting, H., \& Memon, M. A. (2018). Partial Least Squares Structural Equation Modeling (PLS-SEM) using SmartPLS 3.0. Pearson.

75.Richetin, J., Demartini, E., Gaviglio, A., Ricci, E. C., Stranieri, S., Banterle, A., \& Perugini, M. (2019). The biasing effect of evocative attributes at the implicit and explicit level: The tradition halo and the industrial horn in food products evaluations. Journal of Retailing and Consumer Services. https://doi.org/10.1016/j.jretconser.2019.101890

76.Rizwan, M., Javed, P. A., Aslam, J., Khan, R., \& Bibi, H. (2014). The relationship of Brand Commitment, Brand Credibility, Perceived Quality, Customer Satisfaction and brand loyalty: an empirical study on Stylo shoes. Journal of Sociological Research, 5(1), 377-404. https://doi.org/10.5296/jsr.v5i1.6572

77.Roy, S. K., Shekhar, V., Quazi, A., \& Quaddus, M. (2020). Consumer engagement behaviors: do service convenience and organizational characteristics matter? Journal of Service Theory and Practice, 30(2), 195-232. https://doi.org/10.1108/JSTP-03-2018-0049

78.Sabine, M., Fassnacht, M., \& Ettinger, A. (2009). Retaining customers with shopping convenience. Journal of Relationship Marketing. https://doi.org/10.1080/15332660903344644

79.Seiders, K., Voss, G. B., Godfrey, A. L., \& Grewal, D. (2007). SERVCON: development and validation of a multidimensional service convenience scale. Journal of the Academy of Marketing Science, 35(1), 144-156.

80.Setyawan, A., \& Kussudiyarsana, I. (2015). Brand Trust and Brand Loyalty, an Empirical Study in Indonesia Consumers. British Journal of Marketing.

81.Shahijan, M. K., Rezaei, S., \& Amin, M. (2018). Qualities of effective cruise marketing strategy: Cruisers' experience, service convenience, values, satisfaction and revisit intention. International Journal of Quality and Reliability Management, 35(10), 2304-2327. https://doi.org/10.1108/IJQRM-07-2017-0135

82.Shamim, A., Ghazali, Z., \& Albinsson, P. A. (2017). Construction and validation of customer value cocreation attitude scale. Journal of Consumer Marketing, 34(7), 591-602. https://doi.org/10.1108/JCM-01-2016-1664

83.Sheeraz, M., Khattak, A. K., Mahmood, S., \& Iqbal, N. (2016). Mediation of attitude toward brand on the relationship between service brand credibility and purchase intentions. Pakistan Journal of Commerce and Social Sciences (PJCSS), 10(1), 149-163.

84.Shin, S., \& Ki, E. J. (2019). The effects of congruency of environmental issue and product category and green reputation on consumer responses toward green advertising. Management Decision. https://doi.org/10.1108/MD-01-2017-0043

85.Smith, T. A. (2020). The role of customer personality in satisfaction, attitude-to-brand and loyalty in mobile services. Spanish Journal of Marketing - ESIC, 24(2), 155-175. https://doi.org/10.1108/SJME-06-2019-0036

86.Spears, N., \& Singh, S. N. (2004). Measuring Attitude toward the Brand and Purchase Intentions. Journal of Current Issues \& Research in Advertising, 26(2), 53-66. https://doi.org/10.1080/10641734.2004.10505164

87.Srinivasan, N., \& Ratchford, B. T. (1991). An empirical test of a model of external search for automobiles. Journal of Consumer Research, 18(2), 233-242.

88.Storey, J. (2017). Theories of consumption. In Theories of Consumption. 
https://doi.org/10.4324/9781315559209

89.Swait, J., \& Erdem, T. (2007). Brand effects on choice and choice set formation under uncertainty. Marketing Science. https://doi.org/10.1287/mksc.1060.0260

90.Swaminathan Sylvia Long-Tolbert Brian Till, S. D., \& Brian Till, U. D. (2006). ASSOCIATION FOR CONSUMER RESEARCH Product Attribute Evaluations: Role of Consumer Experience and Halo Effects Product Attribute Evaluations: Understanding the Role of Consumer Experience and Halo Effects Sylvia Long-Tolbert Drexel. In ACR North American Advances: Vol. NA-33.

91.Sweeney, J., \& Swait, J. (2008). The effects of brand credibility on customer loyalty. Journal of Retailing and Consumer Services, 15(3), 179-193. https://doi.org/10.1016/j.jretconser.2007.04.001

92.Tsang, M. M., Ho, S. C., \& Liang, T. P. (2004). Consumer attitudes toward mobile advertising: An empirical study. International Journal of Electronic Commerce, 8(3), 65-78. https://doi.org/10.1080/10864415.2004.11044301

93.Utami, I., Kusuma, I. W., Gudono, G., \& Supriyadi, S. (2017). Debiasing the halo effect in audit decision: Evidence from experimental study. Asian Review of Accounting, 25(2), 211-241. https://doi.org/10.1108/ARA-10-2015-0105

94.Vila-López, N., \& Rodríguez-Molina, M. (2013). Event-brand transfer in an entertainment service: Experiential marketing. Industrial Management and Data Systems. https://doi.org/10.1108/02635571311324160

95.Visentin, M., Pizzi, G., \& Pichierri, M. (2019). Fake News, Real Problems for Brands: The Impact of Content Truthfulness and Source Credibility on consumers' Behavioral Intentions toward the Advertised Brands. Journal of Interactive Marketing. https://doi.org/10.1016/j.intmar.2018.09.001

96.Wang, S. W., Kao, G. H. Y., \& Ngamsiriudom, W. (2017). Consumers' attitude of endorser credibility, brand and intention with respect to celebrity endorsement of the airline sector. Journal of Air Transport Management, 60, 10-17. https://doi.org/10.1016/j.jairtraman.2016.12.007

97.Wirtz, J., \& Bateson, J. E. G. (1995). An experimental investigation of halo effects in satisfactio. International Journal of Service Industry Management.

98.Wong, A. (2020). Consumer Perceptions of Service Convenience in Hedonic and Utilitarian Retail Settings in China. Journal of International Consumer Marketing, 1-19. https://doi.org/10.1080/08961530.2020.1816866

99.Wong, K. K. K.-K. (2013). 28/05 - Partial Least Squares Structural Equation Modeling (PLS-SEM) Techniques Using SmartPLS. Marketing Bulletin, 24(1), 1-32.

100. Woo, H. (2019). The expanded halo model of brand image, country image and product image in the context of three Asian countries. Asia Pacific Journal of Marketing and Logistics, 31(4), 773790. https://doi.org/10.1108/APJML-05-2018-0173

101. Wu, B. T. W., \& Petroshius, S. M. (1987). The halo effect in store image measurement. Journal of the Academy of Marketing Science, 15(3), 44-51. https://doi.org/10.1007/BF02722170

102. Yeh, T. M., Chen, S. H., \& Chen, T. F. (2019). The relationships among experiential marketing, service innovation, and customer satisfaction-A case study of tourism factories in Taiwan. Sustainability (Switzerland). https://doi.org/10.3390/su11041041

103. Zarantonello, L., \& Schmitt, B. H. (2010). Using the brand experience scale to profile consumers and predict consumer behaviour. Journal of Brand Management, 17(7), 532-540. https://doi.org/10.1057/bm.2010.4

104. Zeigler-Hill, V., Besser, Y., \& Besser, A. (2020). A negative halo effect for stuttering? The consequences of stuttering for romantic desirability are mediated by perceptions of personality traits, self-esteem, and intelligence. Self and Identity. https://doi.org/10.1080/15298868.2019.1645729 